УДК 371.134.016:78(043.3)

Олена Шевченко

Національний педагогічний університет імені М. П. Драгоманова

ORCID ID 0000-0001-7028-8888

DOI 10.24139/2312-5993/2019.05/206-216

\title{
МЕТОДИ ФОРМУВАННЯ ВОКАЛЬНО-ВИКОНАВСЬКОГО ДОСВІДУ МАЙБУТНІХ УЧИТЕЛІВ МУЗИКИ
}

у статті розглянуто основні методи, які забезпечують формування вокально-виконавського досвіду, а саме: оновлення вокального матеріалу $i$ повторення засвоєного; ескізно-цілісних виконавських ознак; образно-асоціативний; аналітико-формотворчий; активно-перетворювальних дій; порівняльнооцінювальних художній дій; художньо-ціннісного опрацювання вокальних творів. Визначено, що методи мистецького навчання $є$ послідовними логічно вивіреними способами консолідаційної діяльності викладача та студентів, спрямовані на з'ясування художньо-навчальних завдань. Доведено, що використання різних методів у роботі зі студентами сприяло прояву позитивної динаміки у формуванні вокальновиконавського досвіду в прочесі вокальної діяльності.

Ключові слова: метод, формування, вокально-виконавський досвід, майбутній учитель музики, формування вокально-виконавського досвіду.

Постановка проблеми. В умовах сьогодення особливої значущості приділяється питанням забезпечення успішної професійної діяльності майбутніх фахівців. Складність і специфічна спрямованість діяльності музиканта-педагога висувають особливі вимоги до його художньої грамотності, освіченості, компетентності, культури. У результаті вивчення наукової літератури можемо підкреслити, що питанням, пов'язаним із підготовкою майбутніх фахівців музичного мистецтва, приділено велику увагу. Проте, зауважимо, що проблема формування вокальновиконавського досвіду як основи ефективної діяльності майбутніх учителів музики ще має резерви для більш повного з'ясування.

Аналіз актуальних досліджень. У науковій літературі означена проблема висвітлена з різних аспектів. Цінність для даного дослідження мають наукові розвідки, присвячені розумінню та тлумаченню поняття «досвід». Так, у контексті філософського підходу досліджуване поняття розглядали В.Андрущенко, Н. Вахтомін, В.Іванов, О. Лактіонов, М. Мінаков, І.Надольний, І.Фролов, В.Шинкарук та ін.; 3 позицій діяльнісного підходу поняття “досвід" трактували такі науковці, як В. Джемс, С. Максименко, Г. Олпорт, В. Роменець, Б. Теплов, Ю. Трофімов та ін.; з точки зору педагогічної науки сутність досвіду визначили Ю. Бабанський, Ей юй Хуа, В. Краєвський, Н. Мойсеюк, М. Сметанський, Сяомань Чжу, Сяо Су, А. Хуторський та ін. 
Теорія та методика музичного навчання налічує значну кількість досліджень, присвячених підготовці фахівців музичного мистецтва (О. Андрейко, Бянь Мен, Ван Бін, Ге Де Юуй, І.Гринчук, В.Гусак, Л. Гусейнова, О. Єременко, К. Завалко, Н. Згурська, Є. Йоркіна, В. Крицький, П. Косенко, О. Ляшенко, Н. Мозгальова, В. Ревенчук, Хоу Юе, Ши Цзюнь-бо та ін.). Проте, зауважимо, що досліджувана проблема представлена лише окремими працями таких науковців, як: Т.Грінченко (формування мистецького досвіду майбутніх учителів музики); О. Щербініна (вивчення особливостей досвіду інтерпретації музики різних епох); І. Сипченко та л. Василевська-Скупа (досвід художньо-педагогічного спілкування); О. Хлєбнікова (особливості формування музично-виконавського досвіду у студентів 3ВО культури). Відповідно, попри значущість кола розглянутих питань, проблема формування художньо-виконавського досвіду майбутніх фахівців з музичного мистецтва у процесі вокальної підготовки поки що не дістала належного наукового висвітлення.

Мета статті - розглянути основні методи, які забезпечують формування вокально-виконавського досвіду.

Методи дослідження. У даному дослідженні для досягнення зазначеної мети використано такі методи, як: теоретичні (аналіз філософської, психологічної, педагогічної, музикознавчої, методичної літератури за проблемою дослідження для виявлення сутності основоположних понять дослідження; узагальнення й систематизація матеріалів для сутнісної характеристики методів формування вокальновиконавського досвіду майбутніх фахівців з музичного мистецтва в процесі вокальної підготовки).

Виклад основного матеріалу. Доцільність розгляду поняття «виконавський досвід» зумовлюється проблематикою обраного дослідження, а також необхідністю розв'язання низки означених суперечностей, а саме між:

- зростаючими вимогами до фахової підготовленості вчителів музичного мистецтва й усталеною практикою вокального навчання;

- теоретичною та виконавською підготовкою студентів та їх здатністю реалізувати набуті знання та вміння у практичній діяльності;

- необхідністю формування вокально-виконавського досвіду та недостатністю в системі підготовки вчителів музичного мистецтва відповідного методичного забезпечення.

Систематизація та аналіз наукової літератури дає можливість зазначити, що категорія “досвід» відіграє вагому роль на сучасному етапі 
розвитку музично-педагогічної освіти. Ретроспективні підходи засвідчують той факт, що категорія “досвід» змінювалася залежно від становлення та надбань філософської думки.

Так, у Давній Греції “досвід» пов'язували з розумом (Аристотель, Платон та ін.); давньоримські мислителі - з пізнанням (Лукрецій, Сенека); давньокитайські філософи вважали, що досвід (як мудрість) $є$ сенсом людського буття і має аксіологічне підґрунтя (Лаоцзи, Хань Фей, Ян Чжу та ін.). Філософські погляди Середньовіччя характеризуються визнанням провідної ролі досвіду в пізнанні, а також розглядом активної діяльності людини як основи формування досвіду (Августин, Ф. Аквінський та ін.). Наукові винайдення західноєвропейських мислителів Нового часу уможливили тлумачення досвіду як мисленнєвого, логічного феномену.

Багатоаспектний аналіз філософської та психолого-педагогічної літератури сьогодення свідчать про те, що проблема формування досвіду залишається в центрі уваги науковців різних галузевих напрямів.

Так, визначення ролі взаємовпливу об'єктивної реальності й рівня індивідуального досвіту особистості, становлення їі особистісних якостей становить філософський контекст сьогодення. Отже, уся сукупність чуттєвих сприйнять, що набуваються в процесі взаємодії людини із зовнішньою природою та становить основу всіх наших знань про матеріальний світ.

Психологічний аспект проглядається в обґрунтуванні провідної ролі суб'єктивного досвіду в процесі реалізації потенційних можливостей особистості.

Педагогічна наука досліджує досвід у контексті формування й розвитку особистості як суб'єкту навчання.

В аспекті виконавської діяльності означена проблема стала предметом дослідження наукового доробку Л. Бочкарьова, М. Давидова, О. Ростовського, О. Рудницької, Ю. Цагареллі та ін. У працях цих митців формування досвіду музично-виконавської діяльності передбачає якісне усвідомлення музично-теоретичних знань, практичних умінь і навичок опанування й виконання музичних творів.

Зокрема, Л. Лабінцева висвітлює критерії сформованості досвіду музично-виконавської діяльності студентів: уміння аналізувати музичні твори, володіння музично-теоретичними знаннями, практичними вміннями та навичками в процесі виконання музичних творів; самоконтроль виконання музичних творів, наявність виконавської майстерності, виконавської надійності й артистизму (Лабінцева, 2016, с. 50). 
О. Ростовський розглядає «досвід» як засіб формування окремих якостей, умінь, навичок музичної діяльності. Він визначає досвід як сукупність знань і навичок, набутих на основі й у процесі безперервної практичної взаємодії людей із зовнішнім світом; форма засвоєння людиною раціональних здобутків минулої діяльності (Ростовський, 2011, с. 591).

О. Дем'янчук досвід музичної діяльності розуміє узагальнені художньо-естетичні знання, уміння й навички, закріплені в пізнавальній діяльності й морально-естетичній поведінці (Дем'янчук, 1997, с. 20).

А. Бондаренко та Г. Ніколаєва розглядають музично-виконавський досвід у контексті музично-виконавської майстерності та тлумачать як сукупність знань і навичок, які безпосередньо впливають на продуктивність процесу професійної діяльності (Бондаренко та Ніколаєва, 2015).

Для нашого дослідження особливого значення набувають концептуальні положення, обґрунтовані та викладені О. Ребровою. У ї̈ науковому доробку уточнено базові поняття «естетичний досвід», «художньо-естетичний досвід», «ментальний досвід». Складність та конвергентність зазначеного феномену зумовлені конгломератом різновидів досвіду, які забезпечують формування основних компетентностей майбутніх учителів мистецьких дисциплін. Концептуальною основою набуття художньо-ментального досвіду стає підвищення якості фахової освіти від художньої грамотності через освіченість, компетентність, культури до фахової художньої ментальності. В освітньому процесі домінантою формування художньо-ментального досвіду $\epsilon$ осягнення, опанування художній цінностей минулого, їх екстраполяція на сучасність та проективна стратегія в майбутньому (Реброва, 2013).

Л. Бочкарьов, М. Давидов, О. Рудницька, Ю. Цагареллі та iн. вважають, що досвід музично-виконавської діяльності $€$ сутнісною характеристикою особистості виконавця, який досягається шляхом якісного освоєння музично-теоретичних знань, практичних умінь та навичок пізнання виконання музичних творів і вивчення особливостей виконавства відомих музикантів (Бочкарьов, 1997).

Опрацювання наукової літератури щодо розгляду «вокальновиконавського досвіду» дає можливість його визначити як засвоєні особистістю способи відтворення музичних образів з метою донесення їх до слухацької аудиторії, що акумулюють музичні враження й переживання, а також музикознавчі, інтерпретаційні та методичні компетенції, набуті в процесі виконавсько-художньої діяльності.

На підставі запропонованих вище тлумачень поняття «досвід» можемо стверджувати, що формування вокально-виконавського досвіду 
майбутніх учителів музики відбувається на основі формування певних практичних умінь у процесі музично-виконавської діяльності.

На думку О. Хлєбнікової (Хлєбнікова, 1998, с. 1-2), у структурі музично-виконавської діяльності вагому роль відіграють такі вміння, як:

- уміння музично-теоретичного й виконавського аналізу музичного твору, які відображають наявність необхідних знань та навичок пізнання виконавцем нотного тексту, що передбачає визначення жанру, стилю, форми твору; створення теоретичної моделі інтерпретаційного задуму;

- уміння освоєння технології виконання музичного твору, що характеризує процес оволодіння виконавцем музичним нотним текстом (адекватне акустичне відтворення позначень, вибір і освоєння доцільної аплікатури, виявлення та подолання складних для виконання фрагментів, досягнення художньої цілісності виконання);

- психологічна готовність до виконання твору свідчить про наявність знань, умінь та навичок саморегуляції психічного стану й психофункціонального фону в процесі виконання музичного твору;

- уміння аналізувати, контролювати й коригувати виконання музичного твору, що включає сприймання й аналіз (якості відтворення жанрово-стильових ознак, музичної форми, глибини відображення задуму автора); контроль виконання - відповідності реального звучання авторському нотному тексту твору, а також попереднім музично-слуховим уявленням виконавця;

- інтерпретаційні вміння, що відображені у відповідності реального звучання інтерпретаційному задуму й свідчать про наявність техніковиконавської майстерності та артистизму.

Таким чином, формування зазначених умінь - складний багатоаспектний процес, розгортання якого актуалізує значення майстерності, яка складає основу виконавської діяльності та виступає вихідною передумовою поглиблення вокально-виконавського досвіду майбутнього вчителя музики.

Зважаючи на необхідність обґрунтування та розгляду методів формування вокально-виконавського досвіду майбутніх учителів музики, висвітлимо різні тлумачення поняття «метод», «метод навчання», «методика».

Слід наголосити на тому, що не тільки сукупність способів, прийомів складає сутність «методу». Метод виступає системою закономірностей пізнання особливостей становлення та розвитку музичного мистецтва, основних вимог щодо з'ясування мистецьких завдань у різних видах музичної діяльності, досягнення позитивних художніх результатів. 
Крім того, у контексті означеного питання доречно підкреслити, що вокальне виконавство $€$ специфічною художньою галуззю, що передбачає художнє пізнання змістової сутності вокального твору, складання художньовиконавської концепції та ії творчому втіленні у виконавських інтерпретаційних діях. Опрацювання наукової літератури дає підстави розуміти вокально-виконавський досвід майбутнього вчителя музичного мистецтва як засвоєні особистістю способи відтворення вокальних образів 3 метою донесення їх до слухацької аудиторії, що акумулюють музичні враження й переживання, а також музикознавчі, інтерпретаційні та методичні компетенції, ціннісні установки, набуті в процесі художньої діяльності.

У нашій роботі методи мистецького навчання тлумачаться як послідовні логічно вивірені способи консолідаційної діяльності викладача та студентів, спрямовані на з'ясування художньо-навчальних завдань. «Методика» розуміється як сукупність засобів, умов, принципів, пов'язаних у логічну систему з метою досягнення необхідного результату.

3 метою формування вокально-виконавського досвіду майбутнього вчителя музичного мистецтва нами опрацьовано низку методів, які в подальшому мають вплинути на ефективність розробленої методики формування означеного феномена, а саме:

- оновлення вокального матеріалу й повторення засвоєного;

- ескізно-цілісних виконавських ознак;

- образно-асоціативний;

- аналітико-формотворчий;

- активно-перетворювальних дій;

- порівняльно-оцінювальних художній дій;

- художньо-ціннісного опрацювання вокальних творів.

Дамо коротку характеристику кожному із запропонованих методів формування вокально-виконавського досвіду майбутніх фахівців музичного мистецтва.

Метод оновлення вокального матеріалу і повторення засвоєного (за Г. Падалкою), що сприяє більш міцному засвоєнню вокально-навчального матеріалу та враховує гедоністичні підходи в процесі пізнання художніх явищ. До того ж, застосування в навчальній програмі вокальних творів для повторення відіграє неабияку роль у послідовному накопиченні вокальновиконавського досвіду, «виконавського багажу». Використання цього методу впливає також на «творче розкріпачення» студентів (Падалка, 1995).

Метод «ескізно-цілісних виконавських ознак» забезпечує в межах навчального часу, що відводиться на дисципліну «Постановка голосу», 
більш широкому цілісному охопленню студентами жанрово-стильових ознак, а також детальному опрацюванню окремих вокальних творів. Під час реалізації цього методу відбувається проходження достатньої кількості музичного матеріалу за обмежений час, що сприяє накопиченню досвіду художнього сприймання.

Крім того, використання даного методу впливає на виконавське опрацювання вокального матеріалу. Слід наголосити, що ескізне вивчення вокального навчального репертуару дає можливість не тільки його розширити, але й дозволяє вільно ілюструвати та проводити паралелі 3 творами різних стилів і жанрів музичного мистецтва, що забезпечує єдність цілісного охоплення студентами музичного образу, композиторського стилю і також детальну роботу над окремими художніми структурами.

На думку Н.Попович, на основі власних емоційно-естетичних почуттів і переживань, художнього осмислення й узагальнення результатів цілісного аналізу твору майбутні фахівці формулюють професійне оцінне судження, що вимагає індивідуально-творчої самостійної роботи кожного студента й зумовлює поглиблення їхнього вокально-виконавського досвіду (Попович, 2012, с. 257).

Отже, метод ескізно-цілісних виконавських ознак дає змогу поставити перед студентами низку завдань:

- на основі аналізу нотного тексту визначити його стилістичну характеристику, основні складові музичної форми твору;

- вказати на засоби музичної та виконавської виразності, застосовані у творі;

- виявити їхній вплив на емоційно-естетичне сприйняття художньої образності твору.

Методи, розроблені О. Бузовою, «образно-асоціативний» і «аналітико-формотворчий», модифіковане застосування яких ефективно впливає на формування вокально-виконавського досвіду майбутніх учителів музики (Бузова, 2004).

Образно-асоціативний метод передбачає збагачення естетичних переживань на основі утворення та сприймання студентами художньообразних зв'язків між різними видами мистецтва. Емоційний заряд, що міститься в художніх образах поезії, живопису, театру тощо, ефективніше за будь-які словесні пояснення впливає на музично-відчуттєву реакцію студентів, інтенсифікує емоційно-естетичні переживання музики (Бузова, 2004).

Аналітико-формотворчий метод спрямовано на порівняння виражальних і зображальних засобів у різновидах мистецтва й на цій 
основі усвідомлення студентами універсальних та специфічних художніх закономірностей. Цілісний підхід до художньо-порівняльного аналізу, де зміст і форма образів мистецтва розглядаються в нерозривній єдності, виступає принциповим моментом запропонованого методу (Бузова, 2004).

Отже, образно-асоціативний метод передбачає порівняння змістового наповнення образів у різних видах мистецтва, аналітикоформотворчий - орієнтує студентів на зіставлення елементів форми. Таким чином, ці методи дозволяють спрямовувати процес спілкування з різними видами мистецтва на активізацію художньо-естетичного досвіду студентів.

Метод активно-перетворювальних дій, що забезпечує розвиток практично-творчих навичок задля готовності майбутнього педагогамузиканта творчо реалізовувати себе в інноваційному мистецькопедагогічному просторі з урахування соціально-економічних та культурних змін у суспільстві.

Метод порівняльно-оцінювальних художній дій (за В. Орловим) забезпечує спрямованість свідомості студента на власні думки й почуття, оцінку результатів вокальної навчальної діяльності. Цей метод впливає на актуалізацію художньо-навчального досвіду вихованців.

Зауважимо, що вагомого значення в розвитку здатності розуміння художнього змісту вокально-інструментальних творів належить порівняльним операціям. Як зазначають учені, «поза порівнянням, зіставленням, співвіднесенням було б надто утрудненим виявлення естетичної значимості музичних образів» (Падалка, 1995, с. 11).

Метод художньо-ціннісного опрацювання вокальних творів передбачає сприймання студентами, опанування художніх цінностей мистецьких творів та їх виконавське втілення в сучасних умовах.

Висновки та перспективи подальших наукових досліджень. Таким чином, викладений у даній публікації матеріал дає можливість сформулювати такі узагальнення:

- стверджувати про необхідність і своєчасність обраної проблеми;

- висвітлити методи формування вокально-виконавського досвіду майбутніх учителів музики (оновлення вокального матеріалу й повторення засвоєного; ескізно-цілісних виконавських ознак; образно-асоціативний; аналітико-формотворчий; активно-перетворювальних дій; порівняльно-оцінювальних художній дій; художньо-ціннісного опрацювання вокальних творів);

- включення студентів у творчу діяльність, використання різних методів у роботі зі студентами сприяло прояву позитивної динаміки у формуванні вокально-виконавського досвіду в процесі вокальної діяльності. 
Насамкінець підкреслимо, що дана публікація актуалізує далеко не все коло питань у контексті обраної тематики. Вимагають подальшої наукової розробки питання щодо створення педагогічних умов і шляхів формування вокально-виконавського досвіду майбутніх учителів музики у процесі вокального навчання.

\section{ЛІТЕРАТУРА}

Бондаренко, А. О., Ніколаєва, Г. О. (2015). Музично-виконавська майстерність як педагогічна проблема. Науковий часопис Національного педагогічного університету імені М. П. Драгоманова. Серія 14. Теорія і методика мистецької освimu, 17 (22), 12-14 (Bondarenko, A. O., Nikolaieva, H. O. (2015). Musicalperforming skills as a pedagogical problem. Scientific journal of the National Pedagogical University named after M. P. Dragomanov. Series 14. Theory and Methodology of Artistic Education, 17 (22), 12-14).

Бочкарев, Л. Л. (1997). Психология музыкальной деятельности. М.: Изд-во Инстита тпсихологии РAH (Bochkarev, L. L. (1997). Psychology of musical activity. М.: Institute of Psychology of the Russian Academy of Sciences).

Бузова, О. Д. (2004). Поліхудожнє виховання як засіб удосконалення музичної підготовки майбутніх вчителів музики (автореф. дис. ... канд. пед. наук: 13.00.02). Київ (Buzova, O. D. (2004). Poly-artistic education as a means of improving musical training of the future teachers of music (DSc thesis abstract). Kyiv).

Дем'янчук, О. Н. (1997). Педагогічні основи формування художньо-естетичних інтересів школярів. К. (Demianchuk, O. N. (1997). Pedagogical bases of formation of artistic and aesthetic interests of schoolchildren. K.).

Лабінцева, Л. П. (2016). Досвід музично-виконавської діяльності майбутнього вчителя музичного мистецтва. Науковий часопис Начіонального педагогічного університету імені М. П. Драгоманова. Серія 14: Теорія і методика мистецької освimu, 20 (25), 50-54 (Labintseva, L. P. (2016). Experience of musical performance of the future teacher of musical art. Scientific journal of the National Pedagogical University named after M. P. Dragomanov. Series 14: Theory and Methodology of Artistic Education, 20 (25), 50-54).

Падалка, Г. М. (1995). Музична педагогіка: курс лекцій з актуальних проблем викладання музичних дисциплін в системі педагогічної освіти. Херсон: ХДП (Padalka, H. M. (1995). Music Pedagogy: A course of lectures on topical issues of teaching musical disciplines in the system of pedagogical education. Kherson: KhSPI).

Попович, Н. М. (2012). Значення виконавських умінь у формуванні професійноособистісного досвіду майбутнього вчителя музики. Наукові записки Вінницького державного педагогічного університету імені Михайла Коцюбинського. Серія: педагогіка і психологія, 38, 254-258 (Popovych, N. M. (2012). The value of performing skills in shaping professional and personal experience of a future music teacher. Scientific notes of the Vinnitsa State Pedagogical University named after Mykhailo Kotsiubynskyi. Series: Pedagogy and Psychology, 38, 254-258).

Реброва, О. Є. (2013). Теоретичне дослідження художньо-ментального досвіду в проекції педагогіки мистецтва. К.: Національний педагогічний університет імені М. П. Драгоманова (Rebrova, О. Yе. (2013). Theoretical study of artistic and mental experience in the projection of pedagogy of art. K.: National Pedagogical University named after M. P. Drahomanov). 
Ростовський, О. Я. (2011). Теорія і методика музичної освіти. Тернопіль: Навчальна книга "Богдан» (Rostovskyi, О. Үa. (2011). Theory and methodology of musical education. Ternopil: Educational book "Bogdan").

Хлєбнікова, О. В. (1998). Досвід музично-виконавської діяльності і діагностика його срормованості у студентів вузів культури. К. (Khlebnikova, О. V. (1998). Experience of musical-performing activity and diagnostics of its formation in students of HEls of culture. K.).

\section{PEЗЮME}

Шевченко Елена. Методы формирования вокально-исполнительского опыта будущих учителей музыки.

В статье рассмотрены основные методы, которые обеспечивают формирование вокально-исполнительского опыта, а именно: обновление вокального материала и повторение усвоенного; эскизно-целостных исполнительских признаков; образно-ассоциативный; аналитико-формотворческий; активнопреобразовательных действий; сравнительно-оченочных художественный действий; художественно-ценностной обработки вокальных произведений. Определено, что методы художественного обучения являются последовательными логически выверенными способами консолидационной деятельности преподавателя и студентов, направленные на выяснение художественно-учебных задач. Доказано, что использование различных методов в работе со студентами способствовало проявлению положительной динамики в формировании вокально-исполнительского опыта в процессе вокальной деятельности.

Ключевые слова: метод, формирование, вокально-исполнительский опыт, будущий учитель музыки, фрормирование вокально-исполнительского опыта.

\section{SUMMARY}

Shevchenko Olena. Methods of forming vocal-performing experience of future music teachers.

The article discusses the main methods that ensure formation of vocal-performing experience, namely: updating of vocal material and repeating the acquired one (promotes stronger assimilation of the vocal-educational material and takes into account hedonistic approaches in the process of cognition of artistic phenomena); sketch-integral performance features (provides a wider holistic coverage by students of genre-style features, as well as detailed processing of individual vocal works); figurative-associative (envisages enrichment of aesthetic experiences based on the formation and perception by students of artisticfigurative connections between different types of art); analytical-formative (is aimed at comparing expressive and visual means in varieties of art and on this basis students' awareness of universal and specific artistic patterns. A holistic approach to artistic comparative analysis, where the content and form of artworks are viewed in indissoluble unity, serves as a fundamental point of the proposed method); active transformative actions (ensures development of practical and creative skills for the readiness of the future music teacher to realize himself creatively in an innovative art and pedagogical space in the light of socio-economic and cultural changes in society); comparative-evaluative artistic actions (provides orientation of the student's consciousness to his own thoughts and feelings, evaluation of the results of vocal educational activity); artistic-value interpretation of vocal works (involves students' perception, mastery of artistic values of works of art and their performing embodiment in modern conditions). 
It is determined that the methods of art teaching are sequential logically verified ways of consolidating the activities of the teacher and students, aimed at clarifying artisticeducational problems. It is proved that the use of various methods in working with students contributed to manifestation of positive dynamics in the formation of vocal-performing experience in the process of vocal activity.

It is concluded that involvement of students in creative activities, the use of different methods in working with students contributed to the manifestation of positive dynamics in the formation of vocal-performing experience in the process of vocal activity.

Key words: method, formation, vocal-performing experience, future music teacher, formation of vocal performing experience. 